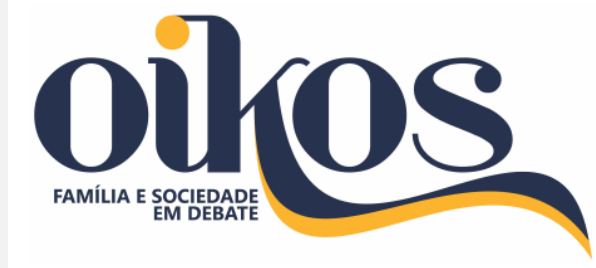

SILVA, Vania Eugênia da; FARIAS, Rita de Cássia Pereira. Gênero e consumo no romance Madame Bovary. Oikos: Família e Sociedade em Debate, v. 30, n. 1, p. 29-48, 2019

\title{
Gênero e consumo no romance Madame Bovary
}

\author{
Gender and consumption in Madame Bovary novel
}

\author{
Vania Eugênia da Silva ${ }^{1}$ \\ Rita de Cássia Pereira Farias ${ }^{2}$
}

\begin{abstract}
Resumo
O artigo trata-se de uma análise sobre a relação gênero e consumo a partir do romance (livro e filme) Madame Bovary. O estudo é de natureza qualitativa, descritiva e documental, pautado na descrição e análise do livro, publicado em 1857, e das cenas do filme, lançado em 2015, que retrata a história de Emma Bovary, moça criada no campo e educada para ser a esposa ideal nos moldes da sociedade francesa do século XIX. Diferentemente da maioria das mulheres daquela época, que não estudaram, Emma cresceu lendo romances que despertaram nela a ilusão de uma vida diferente da qual ela se deparou depois de se casar. Frustrada e infeliz, ela buscou no adultério e no consumo uma fuga da vida medíocre que levava. Contudo, suas transgressões não ficaram impunes, e ela viu seus sonhos amorosos e consumistas serem destruídos pela realidade. Emma sucumbe ao suicídio, visto como a única saída para a sua difícil situação. Madame Bovary faz uma crítica à sociedade burguesa - que aprisiona a mulher em papéis e identidades, bem como à sociedade de consumo, estabelecida após a revolução industrial, que a instigou a um consumo impossível de ser sustentado pela sua condição e classe.
\end{abstract}

Palavras-chave: Madame Bovary. Gênero. Consumo.

\begin{abstract}
The paper presents an analysis of the relationship between gender and consumption in the novel Madame Bovary. Based on the book published in 1857 and in the film released in 2015, the research is qualitative, descriptive and documentary in nature. Emma Bovary, the protagonist, is a country girl raised to be an ideal wife according to the nineteenth-century French society. Unlike most women of that time, she had wide access to books which presented her other worlds and gave her the illusion of a different life than the one she had after getting married. Trying to escape her frustrations and sadness, she seeks in adultery and consumption an option to fill her inner void. However, her transgressions do not go unpunished, and she sees her loving, consumerist dreams shattered by reality, making her seek a drastic solution. The novel criticizes bourgeois society, which oppresses, inferiors, and subordinates women to male domination, and imprisons them in preestablished roles and identities. It also exposes the consumer society, instituted after the Industrial Revolution, which took from Emma the notion of reality, instigating her to a form of consumption that could not be sustained by her class condition.
\end{abstract}

Key-words: Madame Bovary. Gender. Consumption.

\footnotetext{
${ }^{1}$ Doutoranda em Economia Doméstica pelo Programa de Pós-graduação em Economia Doméstica da Universidade Federal de Viçosa. E-mail: vania.eugenia@ufv.br

2 Doutora em Antropologia Social, Professora Associada da Universidade Federal de Viçosa, Viçosa, MG, Brasil. E-mail: rcfarias@ufv.br
} 


\section{INTRODUÇÃO}

O presente trabalho tem como objetivo refletir sobre a relação gênero e consumo a partir do romance Madame Bovary, de Gustave Flaubert. A análise pautou-se no filme, lançado nos Estados Unidos em 12 de junho de 2015, e foi complementada com informações do livro, publicado em 1857. Para a análise dos dados, inicialmente foram expostas informações sobre o autor e a obra, seguidas do contexto histórico e social no qual se passou a trama da personagem principal e, posteriormente, foram feitas discussões sobre as relações de gênero retratadas no romance para, finalmente, trazer as discussões sobre consumo.

A trama de Madame Bovary conta a história de Emma, uma mulher sonhadora, pequenoburguesa, criada no campo, cuja vida era marcada pela literatura sentimental. Bonita e requintada para os padrões provincianos, casa-se com Charles Bovary, um médico do interior tão apaixonado pela esposa quanto entediante. Nem mesmo o nascimento da filha ${ }^{3}$ traz alegria ao seu casamento. Emma, ao sentir-se presa a um indissolúvel casamento, busca na literatura, no adultério e no consumismo uma forma de encontrar a liberdade e a felicidade. Apesar da procura por uma vida plena, ela não consegue sentir-se satisfeita com o que é e com o que tem. Frustrada em suas expectativas, ela se atira em aventuras amorosas e perigosas com amantes, gastos desmedidos, entregando-se a uma fantasia criada a partir da literatura e da realidade decepcionante na qual vivia em Yonville.

A problemática a ser discutida no presente trabalho se refere à questão de como a sociedade define um papel para a mulher. Entretanto, quando ela não se reconhece nesses papéis e identidades e subverte as "normas, regras e valores" impostos, ela é julgada pela sociedade. Embora Madame Bovary seja um romance, a obra retrata a situação vivida por muitas mulheres que, historicamente, viram no casamento e no consumo suas únicas formas de realização, tendo em vista o fato de não terem tido a oportunidade de desenvolver uma carreira profissional. Contudo, há que se ressaltar que existem mulheres com vida profissional desenvolvida, mas que também podem ver o casamento e o consumo como mais uma forma de realização pessoal, ou seja, uma coisa não exclui a outra.

O romance em questão deixa transparecer uma crítica social do autor à sociedade burguesa desmascarando a romantização da condição servil da mulher. No século XIX, a sociedade de consumo se formava, impulsionada pela indústria crescente que produzia cada vez

\footnotetext{
${ }^{3}$ O filme na versão de 2015 não aborda o fato de Emma Bovary ter sido mãe. As informações sobre a gravidez, o nascimento e a relação com sua filha foram obtidas no livro.
} 
mais e estimulava o consumo, apelando para necessidades pessoais, dependência econômica e social, além de promessas de felicidade.

\section{O AUTOR, A OBRA E O CONTEXTO HISTÓRICO E SOCIAL}

Gustave Flaubert ${ }^{4}$ nasceu em Rouen, França, em 12 de dezembro de 1821. Viveu 58 anos, vindo a falecer em 08 de maio de 1880. Começou a escrever ainda cedo, na mesma época em que fora reprovado para a Faculdade de Direito de Paris. Flaubert vivia como um aristocrata, sem trabalhar, aproveitando a vida junto aos amigos e à sua primeira amante. Depois de uma viagem ao Oriente decidiu se tornar escritor em tempo integral. Abandonou sua amante e se envolveu com Louise Colet, com quem viveu até a morte dela. Recluso na propriedade da família, em Croisset, iniciou a obra Madame Bovary, que demorou cinco anos para ser concluída (HEINEBERG, 2016).

O romance ${ }^{5}$ foi publicado, primeiramente, com o subtítulo Costumes do interior, em quatro folhetins, no periódico La revue de Paris, em 1856, e em um livro constituído por dois volumes, em 1857. A temática do adultério e o tratamento realista e psicologicamente profundo das fraquezas humanas logrou muita admiração e também muita reprovação. Vários escritores de renome compreenderam que o romance francês do século XIX tinha em Flaubert o seu mestre. Já as classes conservadoras escandalizaram-se com a obra. Assim, em 1857, Gustave Flaubert sofreu um processo no Tribunal de Paris por ofensa à moral pública e religiosa (HEINEBERG, 2016). Com a icônica frase "Emma sou eu", o autor foi inocentado da acusação, e o romance Madame Bovary ganhou ampla visibilidade.

A frase "Emma sou eu" denotava que Flaubert, assim como Emma, odiava a hipocrisia, a sujeição feminina, a religião, a sociedade burguesa e a moral da época. Flaubert se envolveu com algumas mulheres casadas ou separadas, e, a exemplo de sua figura literária, foi muito mal visto por críticos, pela Igreja e por vários de seus pares (MICHILES, 2012).

O autor do romance, Flaubert, criticou a todos: interioranos e parisienses, homens e mulheres, apaixonados e céticos. Emma Bovary é um dos personagens mais debatidos da literatura universal. Alguns a veem como sofredora irremediável que não consegue romper com os laços que a prendem, outros a veem como uma anti-heroína adúltera e consumista, e outros a consideram uma heroína que insiste em romper com a visão de mundo que a cerca. Há quem

\footnotetext{
4 Parte das informações sobre a biografia do autor, Gustave Flaubert, foi extraída do prefácio da obra traduzida por Ilana Heineberg, na versão brasileira reimpressa em 2016, pela editora L\&PM.

${ }^{5} \mathrm{O}$ termo romance foi utilizado por se tratar do gênero da trama, independentemente se está se falando do livro ou do filme. No caso da obra em análise, primeiramente, esta foi lançada como livro e depois tornou-se filme.
} 
considere que Emma Bovary era a sombra, o lado sombrio e obscuro de Gustave Flaubert; outros ponderam que a intenção do autor ao escrever o romance foi traçar uma crítica à sociedade burguesa da época (MICHILES, 2012), que pregava ideais de feminilidade, de masculinidade e de família e, também, à sociedade de consumo, ávida por transformar os indivíduos em pessoas consumistas, a fim de alavancar a produção.

Independentemente dos julgamentos que recaem sobre Emma Bovary, o romance mostra uma mulher que rompeu com os preceitos femininos da sociedade burguesa da França do século XIX, transgredindo a moral religiosa, econômica e social. As lutas de Emma foram reafirmadas cem anos depois com o início da segunda onda do movimento feminista, que buscava condições de igualdade feminina, direito à liberdade da mulher, à educação, à carreira profissional, à sexualidade, ao trabalho remunerado fora do âmbito doméstico e o fim da opressão masculina. Pinto (2003) ressalta que o movimento feminista sofreu e, ainda sofre, muita repressão e resistência pela parcela masculina que busca manter o status quo.

O filme inicia-se e termina com a cena na qual Emma Bovary corre pelo campo sob neblina e orvalho. Seu modo estranho de se movimentar denota que ela não está se sentindo bem e cai deitada sobre a relva. As cenas seguintes remetem ao passado dando conta da história da menina que viria a se tornar Madame Bovary. Emma aprende "habilidades domésticas" no colégio católico o qual frequentara. Ao se preparar para deixar o convento, ela pronuncia sua primeira fala no filme, rogando repetidas vezes: "- Por favor, Deus, que ele seja o homem certo", revelando, desse modo, que ela estava prestes a se casar com um homem que mal conhecia ou que não amava, o que era comum na época dos casamentos arranjados. O apelo religioso e o desejo de ter um casamento acertado, como a maioria das moças da época, apontam para o ideal de feminilidade de mulher pura e casta, socialmente esperado de uma futura mãe de família, que geraria a seu marido filhos legítimos, aptos para receberem a herança familiar e perpetuar o nome da família. Até então, Emma não demonstra intenção de transgredir a moral da época, algo que não foi possível de manter, diante da vida pacata e monótona que o casamento lhe proporcionou.

O homem com quem Emma se casaria tratava-se de Charles Bovary, que na infância fora um homem pobre e não excepcionalmente inteligente, mas que, com grande esforço, se tornara médico na província de Yonville, na França. Embora fosse apaixonado e devotado à Emma, Charles era muito acomodado, pacato e sem grandes ambições na vida. Ele era viúvo e havia se encantado por Emma tão logo a conhecera na casa de seu pai, que era um de seus pacientes. O pai de Emma, homem do campo abastado e oportunista, mas sem tato para os negócios, fazia gosto pelo casamento da sua filha com Charles, pois o tinha como bom homem e bom médico, 
além de ver nele a chance de casar a filha sem despender muito dinheiro com dote. Bonita e recatada, Emma tem a chance de realizar o sonho das moças da época, principalmente as que seguiam as cartilhas dos romances, nos quais o casamento era o destino manifesto de toda moça de família. Emma não demonstra grande entusiasmo ao aceitar a proposta de Charles, mas também não manifesta desgosto.

A falta de intimidade e afinidade entre o casal é notável na cerimônia e na festa de casamento, ocasião em que Emma parece estar aflita, angustiada, ansiosa e triste. A noite de núpcias é ainda mais frustrante para Emma, que se depara com um marido sem romantismo, diferentemente daquele com o qual ela sonhara ao ler os romances. A relação sexual é fria, sem carícias, sem sentimento e emoção, uma vez que o marido não se preocupa em proporcionar prazer a ela, fato também comum na época em que o romance Madame Bovary foi escrito, na qual não havia preocupação com o prazer sexual feminino.

Com o passar dos dias, Emma se sente incomodada com sua vida pacata, monótona e entediante e se esforça para descobrir paixão em sua vida conjugal. Porém, Charles é um homem conservador, metódico, rotineiro e avesso a novidades. Assim, Emma descobre que o homem com quem se casara não lhe provoca nada do que julgava ser o amor, e segue seus dias dividindo seu tempo entre tocar piano e bordar.

Emma se sentia incompleta e vazia vivendo sua vida pacata, bem diferente da que se apresentava nas revistas, folhetins e livros que retratavam uma vida repleta de emoção, romantismo e luxo. Em meio a seus dissabores e monotonia, surge Monsieur Lheureux, vendedor de roupas, perfumes, acessórios e objetos de decoração, um agiota inescrupuloso, que introduz Emma ao hábito do consumismo. Relutante num primeiro momento, Emma resiste à tentação dos objetos e roupas luxuosas oferecidas pelo vendedor, mas o mercenário Monsieur Lheureux Ihe oferece crédito e ela se deixa seduzir pelo brilho das peças luxuosas: vestidos elegantes, chapéus majestosos, joias, adornos para o corpo, sapatos finos, tapetes de origem asiática, cortinas suntuosas, dentre outros.

Emma conhece os amigos de Charles que moram na mesma província. Entre eles, o escriturário Léon Dupuis, com quem Emma logo tem afinidade, visto que ambos são apaixonados por arte e literatura. Léon também compartilha do ideal de Emma no que se refere a uma vida com mais emoção e entusiasmo do que a vida na província. Ele se apaixona por Emma, mas tem receio de se declarar e ser rejeitado, pois a considera a mulher perfeita. Ela, por sua vez, se sente culpada por sentir desabrochar sentimentos por Léon. Quando ele se declara, Emma resiste e decide se tornar uma esposa o mais virtuosa possível. Ela passa a se dedicar mais em agradar ao marido, elaborando pratos mais requintados para o jantar, reestruturando o jardim 
para que ele pudesse comtemplar a natureza, dentre outros investimentos. Contudo, Charles não percebe o esforço de sua esposa e reage indiferentemente aos agrados que ela tenta lhe proporcionar.

Léon decide ir para Rouen. Emma fica muito deprimida, lamenta pela vida e pelo casamento entediante e não se conforma em viver na província e nem com a falta de ambição do marido. Charles, porém, não percebe o interesse de Emma pelo amigo, apenas acredita que sua tristeza é porque ela estivesse doente.

Em um atendimento médico na casa dos Bovary, Emma conhece o Marquis Rodolphe Boulanger, um conquistador inveterado, que se encanta por sua beleza e convida o casal para participar de uma caçada que aconteceria nos próximos dias. Na caçada, a beleza de Emma é o centro das atenções. Ela usa um elegante e vistoso vestido amarelo que comprou do Monsieur Lheureux, o que é percebido por todos, inclusive pelo Marquis, que busca impressioná-la.

Emma segue consumindo objetos de decoração para o lar como cortinas, lençóis, candelabros de ouro, tapetes e, também, suntuosos vestidos e chapéus, única forma em que ela se sente realizada.

Emma reluta contra seu desejo e não cede às tentativas do Marquis. Entretanto, ela não consegue se conter por muito tempo e o procura na residência dele, sucumbindo aos seus desejos. Pela primeira vez, Emma sente prazer na relação sexual. Contudo, o Marquis não está apaixonado por ela, apenas aprecia a conquista. Assim, além do consumo, Emma passa a buscar realização e sentido para sua vida no adultério.

Após experimentar o prazer sexual, ela começa a rejeitar o marido e implora para que o amante a leve para longe dali, mas recebe uma carta do Marquis abandonando-a. Ela sofre compulsoriamente e adoece. Os dias seguem entediantes e ela continua consumindo e se endividando cada vez mais.

Percebendo a tristeza e o abatimento de Emma, Monsieur Lheureux oferece ao casal convites para assistirem a um recital em Rouen, aproveitando a ocasião para levar Emma a adquirir mais mercadorias. No recital, o casal Bovary reencontra Léon, que está trabalhando em um escritório enquanto termina seus estudos. Ele convida o casal para permanecer em Rouen e assistirem a outro recital no dia seguinte. Charles se recusa, mas sugere que Emma fique para assistir na companhia de Léon. Eles não vão ao recital, mas têm um encontro amoroso, marcado pela sedução e prazer.

Charles não se dá conta de que está deixando Emma à mercê de um futuro amante, pois nunca se atentou para as carências de sua esposa, já que lhe parecia ser suficiente ter uma esposa bonita, elegante e requintada para ostentar à sociedade e ser servido por ela. 
Na volta ao vilarejo, Emma recebe a notícia da morte do pai de Charles, ocasião em que o vendedor começa a lhe cobrar a dívida e a chantageá-la. Emma convence Charles de que precisa de aulas de piano para se aperfeiçoar, quando na verdade começa a ir constantemente para Rouen para se encontrar com Léon. Emma vive dias felizes ao lado de seu amante, enquanto Charles não desconfia da traição da esposa.

Monsieur Lheureux entrega uma carta de cobrança a Charles, que descobre a dívida da esposa, fica perplexo e oferece a casa como pagamento da dívida. Emma procura Monsieur Lheureux para negociar, mas ele quer a herança de Charles como pagamento. Emma procura Léon em Rouen para que ele assuma o romance, mas ele também a abandona.

De volta ao vilarejo, Emma descobre uma ordem da justiça para recolher tudo o que há em sua residência, como pagamento da dívida. Ela novamente procura Monsieur Lheureux para mais uma tentativa de negociar a dívida, e ele sugere que ela procure o Marquis Rodolphe, que está de volta à província, para que ele a ajude. O Marquis se nega a ajudá-la. Inconsolável e desesperada, Emma se dispõe a deitar-se com o Monsieur Lheureux, que se recusa.

Ao ver-se abandonada por seus amantes, falida, insatisfeita e infeliz, Emma Bovary volta para casa, apanha um frasco de ácido arsênico, ingere a substância, corre pelo campo e cai. ${ }^{6}$

A trama de Madame Bovary se passa na França da segunda metade do século XIX, época marcada pelas revoluções de 1848, ou seja, o cenário onde a trama aconteceu foi o momento "pós-revoluções". Essas revoluções marcaram profundamente a França e trouxeram esperanças para o povo.

Uma das grandes marcas que a Revolução Francesa deixou para a sociedade foi a redefinição de valores. De acordo com Prescinca (2013), nesse momento, os espaços com relação à atuação social dos gêneros estavam definidos da seguinte forma: carreiras abertas ao talento e ao exercício das energias individuais para os homens; e o casamento por amor era a grande expectativa para as mulheres.

Enquanto algumas mulheres buscavam se realizar nos romances, outras aproveitavam o clima revolucionário para se dedicarem ao movimento sufragista e à busca pelos direitos políticos e pela emancipação feminina. Uma dessas mulheres revolucionárias era Marie Olympia de Gouges que, dois anos depois da publicação da Declaração dos direitos do homem e do cidadão de 1789, embasando-se nos filósofos Locke, Rousseau e John Stuart Mill, escreveu a Declaração dos direitos da mulher e da cidadã, que continha 17 resoluções que expressavam sucintamente as condições para a igualdade das mulheres.

\footnotetext{
${ }^{6}$ Embora o filme inicie e termine com a cena de Emma Bovary correndo pelo campo e caindo depois de tomar o ácido arsênico, o livro diz que ela ingeriu o veneno em casa e ficou agonizando por horas até falecer, tendo seu marido ficado bastante desolado e sofrido muito.
} 
Gouges apresentou sua declaração aos legisladores, membros da Assembleia Nacional da França. Ao reivindicar as liberdades democráticas para as mulheres, Gouges defendia "que as mulheres deviam ter todos os direitos que os homens têm, inclusive direito de propriedade e liberdade de fala". Adicionalmente, defendia "que as mulheres deveriam ter todas as responsabilidades recíprocas" e "desempenhar todos os deveres públicos", como pagar impostos e serem punidas com a plena severidade da lei, caso cometessem um crime (NYE, 1995, p.23).

No caso de Emma Bovary, ela não pertencia ao grupo das mulheres revolucionárias, mas ao grupo das jovens românticas que sonhava com a liberdade e a felicidade; os ideais revolucionários não lhes tinham sido apresentados como possibilidade no contexto da cidadezinha afastada do centro da revolução parisiense.

Pelo perfil de Emma Bovary, caso a luta feminista tivesse chegado a ela, certamente ela teria agido de forma revolucionária, pois era uma mulher com comportamento que diferia das mulheres de seu tempo.

Segundo Prescinca (2013), aquele era um momento "pós-revoluções" na França, em que grande parte da população estava esperançosa para construir sua própria história, buscando autonomia social. Entretanto, diante do desconhecimento dos ideais revolucionários e da luta feminista, Emma se limitava a uma vida monótona e de sonhos, como a maioria da população feminina francesa da época. Conforme Rago (2015), no contexto social da época,

[...] o papel da mulher era ficar dentro de casa e cuidar dos filhos. Os homens circulavam e tinham acesso ao espaço público e cultural, aos prazeres, aos restaurantes. Era uma época em que predominava a ideologia da domesticidade, dos discursos que afirmavam que a mulher nasceu para ser mãe e para cuidar do lar e da família, apesar de sua crescente entrada no mercado de trabalho (RAGO, 2015).

Sendo Emma Bovary uma mulher insatisfeita com o seu estilo de vida, ela buscou preencher no adultério e no consumo sua falta de realização pessoal, afinal, o tipo de consumo traz um marcador de gênero que merece ser analisado na obra.

\section{MADAME BOVARY E A QUESTÃO DE GÊNERO}

De acordo com Pinto (2003), desde o início da civilização, a divisão sexual do trabalho já era clara e definida: aos homens cabiam a pesca e a caça, enquanto as mulheres deveriam cuidar dos filhos, plantar hortaliças, se dedicar à fabricação de objetos de argila e barro, originando, assim, a base da sociedade patriarcal que considerava as mulheres frágeis, incapazes, inferiores e dependentes de um homem para comandá-las e decidir por elas. Essa 
mentalidade da sociedade patriarcal, marcada pela dominação masculina, perdura até os dias atuais, embora com menor intensidade, visto que ainda vivemos resquícios desse sistema.

No caso de Emma Bovary, por ser uma mulher bonita, criada no campo e educada segundo os padrões estabelecidos pela sociedade patriarcal, ela reunia todas as qualidades esperadas e desejáveis para uma mulher da França da segunda metade do século XIX.

Essa construção do feminino idealizada pelas convenções sociais no contexto da cultura acaba por aprisionar a mulher em uma posição de resignação e submissão ao sexo masculino (MEDEIROS; MEDEIROS, 2017). Como parte das convenções sociais, o termo Madame, no título da obra, já traz o indício de tratar-se de uma mulher casada, como também o sobrenome Bovary que pertence ao marido de Emma, Charles Bovary, traço cultural que revela a mulher como propriedade do marido e ausência da propriedade de si.

No sistema patriarcal em que o homem se impõe como o soberano, a dominação é um aspecto básico dessa formação, cuja opressão é necessária para controlar as mulheres, trazendo empecilhos para que elas não mudem tal situação (PINTO, 2003).

Emma Bovary, embora criada nesse sistema, sente-se desconfortável por não se reconhecer nesses papéis e não se identificar com o estereótipo idealizado para a mulher. Diante da discordância com o sistema reinante, Emma lutou contra as barreiras da moral, da religião e da lei, mas não se via em condições materiais ou de apoio grupal que the oferecessem meios para sair daquela situação de não realização pessoal.

O posicionamento de Emma de ceifar a própria vida após tentativas de rompimento com os padrões sociais pode ser visto como uma forma de denúncia à violência social sofrida pelas mulheres condicionadas a viver em uma sociedade patriarcal que dá origem ao papel transgressor de uma mulher questionadora e que luta por sua emancipação (RAGO, 2015; MEDEIROS; MEDEIROS, 2017).

O fim destinado à Emma no romance mostra que as formas como os homens driblam as convenções impostas pela sociedade são bem diferentes de quando se trata de uma mulher (RAGO, 2015). No século XIX, eram poucas as mulheres que tinham condições de serem escolarizadas e receberem formação política e cidadã, pois a mulher não era vista como sujeito de direito, e sequer lhe era permitido sentir prazer na relação sexual, conforme ressalta Rago (2015).

Em relação à educação, quando a mulher podia estudar, o ensino recebido se resumia às primeiras letras (RAGO, 2015). A maioria casava-se muito cedo por casamentos arranjados pelo pai, de acordo com seus interesses financeiros. Reforçava-se, através desse padrão de pouco ou quase nenhum estudo e casamento precoce, que a função da mulher era procriar, cuidar dos 
filhos e ser dona de casa. Seu papel era definido pela Igreja, pela cultura e pela tradição, que estabeleceram um ideário de mulher marcado por julgamentos que as inferiorizam física e mentalmente, reservando-lhe unicamente as tarefas domésticas e de procriação, atribuindo-lhes um status secundário na sociedade (ORTNER, 1979).

Rago (2015) menciona que, naquela época, estava em ascensão uma medicina que referendava uma suposta superioridade masculina. Às mulheres, cujo corpo é distinto do masculino, caberiam dedicar-se à maternidade e evitar circular pela esfera pública para não contrariar a sua "natureza" doméstica.

Sob esse raciocínio, as mulheres eram consideradas pejorativamente imaginativas e pouco aptas a pensar, a ler ou a escrever. Quando o faziam, era por meio de delírios. O debate moral da época dava ênfase ao trabalho quando se discutia a masculinidade, e ao sexo quando se tratava do lugar das mulheres. Os desviantes do sexo masculino eram vistos como "delinquentes", enquanto as do sexo feminino seriam "degeneradas" (RAGO, 2015).

Esse traço de sua personalidade é visualizado na mulher de modo geral. Como afirma Ortner (1979), a mulher pode até parecer mais à mercê da "natureza" do que o homem, mas, tendo consciência, ela pensa e fala, gera, comunica e manipula símbolos, categorias e valores, participa dos diálogos humanos não somente com as mulheres, mas, também, com os homens.

Por conta de sua consciência e participação no diálogo social, a mulher é reconhecida como participante da cultura. Portanto, ela surge em uma posição intermediária entre a natureza e a cultura numa escala de transcendência inferior à do homem.

Contrária às expectativas da época, Emma era uma mulher que pensava e agia contra a moral que a sociedade da época pregava, tinha consciência de que ao homem era dada maior liberdade, por isso, ela lutou contra as barreiras sociais de seu tempo. Emma buscou desconstruir o parâmetro de mulher ideal ao longo da trama, não pelo seu discurso, mas por suas ações: ela trai, mente, não gosta da filha, e não é o modelo de esposa bem-comportada esperado das mulheres, embora tenha sido criada para tal.

A desconstrução por Emma das expectativas sociais começa pelo casamento, uma instituição utilizada para manter o status social, o qual caberia às mulheres contribuírem para o sucesso familiar através de uma postura de anfitriãs, esposas ou donas de casa. Conforme Medeiros e Medeiros (2017), é contrariando esse pensamento tradicional e essa visão romântica que a personagem Emma Bovary desconstrói uma série de valores hipócritas da sociedade burguesa do século XIX.

Emma não se opôs ao casamento, seguiu o curso da vida em sociedade, percorrendo, conforme Beauvior (1970), o destino que a sociedade propõe a mulher: o casamento, sendo que 
a maioria delas é ou já foi casada, ou se prepara para ser ou sofre por não ser. Diante desse ideal feminino, algum tempo depois que se casa, Emma busca a felicidade sem preocupar-se com o seu papel de esposa e dona do lar. Entretanto, em pouco tempo, ela começa a perceber que aquele tipo de relacionamento não Ihe traria realização e começa a se ressentir de sua vida monótona e entediante ao lado de um homem satisfeito com sua vida prosaica.

A consciência de Emma sobre a distinção em relação à liberdade de homens e mulheres é retratada quando ela engravida e deseja ter um filho, pois sabe que como homem ele seria livre, podendo percorrer paixões, atravessar obstáculos e atingir a felicidade, ao passo que a menina seria impedida, tendo contra si as dependências da lei, da moral e dos costumes.

Ter um filho seria uma vingança contra as restrições a que uma mulher de seu tempo tinha que se curvar. Ao dar à luz a uma menina, Emma se decepciona, pois para ela uma menina significava a continuidade de um destino em que pouco se podia interferir (AGRA, 2015).

Como Emma não se identificava com o papel de mãe, não tinha afeição pela filha e detestava amamentar, ela a rejeitava e a maltratava, deixando a menina aos cuidados da ama de leite. Quando precisava visitar a filha na casa da ama de leite, Emma parecia viver um sacrifício. A relação de Emma com sua filha faz coro às constatações de Elizabeth Badinter (1995) em seu livro “Um amor conquistado: o mito do amor materno”, no qual a autora busca desconstruir o caráter natural do amor materno e o papel de mãe que fora historicamente atribuído à mulher. Badinter (1995) preocupa-se em compreender como um sentimento pode passar por variações tão profundas, indo de uma indiferença aos cuidados dos filhos para uma situação em que a mulher é vista e cobrada socialmente pelos cuidados da prole.

Embora Rago (2015) pondere que não é preciso ser mãe para ser mulher, a mulher que não deseja a maternidade é cobrada pela sociedade como se ser mãe fosse a única explicação para a existência feminina. Para Badinter (1995), essas concepções são constituídas nas e pelas relações de gênero, nas quais os discursos masculinos, além de inferiorizarem a condição da mulher, exigem dela a exclusividade do cuidado e da amamentação dos filhos, tendo a figura de "boa mãe" como o tipo ideal a ser seguido.

A autora contextualiza a construção do amor materno ao afirmar que, até meados do século XVIII, a maternidade se dava em termos de indiferença e até mesmo rejeição, como fora o caso de Emma Bovary em relação à sua filha Berthes. As taxas de mortalidade infantil eram altas, e nada se fazia sobre isso. Assim, essa falta de apego aos filhos pode ser explicada como uma forma de não sofrer caso a criança viesse a falecer. As crianças eram vistas como "peso" para a família, e muitas mães, assim como Emma, se recusavam a amamentar para evitar 
deformações em seus seios e terem que abrir mão de seu tempo livre. Desse modo, muitas crianças eram enviadas a amas de leite, quando não, abandonadas em conventos e abrigos.

Insatisfeita com o casamento, a maternidade e a mediocridade de seus dias, Emma buscava, ainda de forma mais voraz, na literatura romântica, o preenchimento do vazio que sentia. Diante das identificações imaginárias proporcionadas pela leitura, ela se esforçava para sentir emoções compatíveis com a paixão. Entretanto, seu marido, Charles, não era capaz de satisfazer as experiências excitantes que Emma ansiava, pois considerava que felicidade, embriaguez, paixão e satisfação sexual não faziam parte do repertório possível para as "moças de família" daquele tempo (PINTO, 2003; MICHILES, 2012; AGRA, 2015).

Assim, Emma sentia-se angustiada, mas não sabia explicar para si mesma as causas e o porquê de sua infelicidade. Aprisionada numa vida que para ela era insignificante, ela reconhecia a existência de um problema, porém não sabia defini-lo, não entendia o que lhe faltava, o que Ihe ocorria. Tal situação é chamada de "problema sem nome", por Friedan (1971), em seu livro "A mística feminina”, cujo termo aponta o reducionismo dado à vida de muitas mulheres circunscritas à domesticidade.

A mística feminina pregava, por meio de revistas e outros meios, que não havia outra maneira de ser heroína a não ser tendo bebês e vivendo desprovidas de qualquer desejo. Tal condição se expressa na dualidade das percepções femininas: de um lado a mulher pura, no alto de um pedestal, estereótipo de modelo a seguir, e de outro, a prostituta, símbolo de leviandade, desejos carnais, a ser evitado. O "problema" sem nome de que muitas mulheres, como Emma, se queixavam, resultava de uma insatisfação pessoal que poderia ser facilmente resolvido caso as mulheres seguissem o que indicava a leitura de revistas direcionadas a elas: novos filhos, novos cursos de bordados e artesanatos, que exigiam infinita concentração.

Friedan (1971) enfatiza que viver de acordo com a mística supõe uma reversão da história e uma desvalorização do progresso humano. Mediante a mística, muitas mulheres foram "adaptadas" ao espaço doméstico não nos moldes de um sistema autoritário, mas por instrumentos dolosos e veiculados pelo marketing, pelas propagandas, pelos produtos e suas obsolescências programadas com a finalidade de estabelecer um falso prestígio e necessidade da mulher à família.

As análises de Friedan (1971) possibilitam compreender o meio cruel ao qual Emma foi submetida, pois além de ter sido criada em um sistema de autoridade patriarcal que tentou moldá-la a seus preceitos, ela passou a vida lendo revistas que influenciavam o seu consumo e fomentava o desejo por uma vida diferente da que vivia. 
Retomando a questão da inquietação de Emma diante do desconforto em assumir um papel e uma identidade na qual ela não se reconhecia, ela começa a se indagar por que havia se casado. Segundo Agra (2015), o maior drama de Emma reside na audácia de viver seus próprios sonhos sabendo da sua posição social de mulher, de seu universo real restrito, de seu espaço doméstico e do seu destino que é o casamento, isto é, a tragédia de Emma é não ser livre.

A transgressão de Emma perante a sociedade na qual estava inserida se dá pela traição. Sentindo-se presa a um casamento indissolúvel e ávida por liberdade e uma vida diferente, cheia de aventuras, encantos e emoções prometidas pelos romances em folhetins, Emma se entregou ao adultério, que, principalmente, o feminino, era um grande tabu na época.

Entretanto, Agra (2015) reitera que as relações de Emma com os amantes eram plenas de fantasias, clichês e situações romanescas, uma vez que ela buscava em outros homens a saciedade de suas frustrações amorosas, o que lhe dava a certeza de seu grande e inexprimível vazio.

Para Medeiros e Medeiros (2017), as relações extraconjugais de Emma seguiram um projeto paralelo ao do casamento: sedução, prazer, monotonia, desgaste e desilusão, o que ela tentou compensar com a possessividade e o consumo.

Frustrada no amor e cheia de dívidas, levando seu marido à falência, Emma não vê outra solução senão o suicídio, pois na época e no meio em que viveu, suas transgressões não a deixariam impune.

Assim, Emma foi tragada pelo real que tanto tentou burlar. Ao ler, ela criava múltiplos sentidos diferentes daqueles que os autores queriam dizer, recortando aquilo que a consolava e a confortava perante a vida vazia que levava. Entretanto, o real implacável destruiu seus sonhos amorosos e demonstrou a força esmagadora do dinheiro.

\section{MADAME BOVARY PELA PERSPECTIVA DO CONSUMO}

Além da transgressão do adultério e do desprezo pela filha, outro grande desvio das normas tradicionais de comportamento cometido por Emma foi o consumo em excesso, o que levou seu marido à falência. Madame Bovary e sua família se inseriam no estrato social da pequena burguesia, a qual era considerada uma das bases da ética do trabalho e da poupança.

Apesar de não ser tão expressivamente privilegiada, visto que a profissão de seu marido, médico, não era naquela época tão valorizada financeiramente, a família Bovary ainda era 
considerada membro de uma classe privilegiada quando comparada com a classe operária. Assim, o consumo conspícuo de Emma representava uma ameaça ao patrimônio familiar.

Veblen (1899) define o consumo conspícuo como um consumo altamente visível, emblema de classe, que traz notoriedade a partir da aquisição de bens luxuosos que mostram a outros membros da sociedade a riqueza econômica e material de seu possuidor. Um exemplo disso é quando Emma compra candelabros de ouro para sua sala de jantar. Não é o valor utilitário dos candelabros que importa a ela, mas o valor significante altamente conspícuo de riqueza, pelo qual ela receberá admiração social.

A partir desse conceito, Veblen (1899) traz a noção de "ócio conspícuo", isto é, a elevada quantidade de tempo que os membros da classe ociosa gastam em busca de atividades que não são nem econômica nem socialmente produtivas. O ócio implica em ausência de trabalho e, para os membros dessa classe, o uso não produtivo do tempo pode alavancar seu prestígio social e sua posição de classe.

Em um momento em que não era uma possibilidade a profissionalização feminina, Emma Bovary passava seus dias na ociosidade, lendo revistas e folhetins que traziam romances, figurinos e objetos para decoração e uso pessoal. Esses materiais impressos traziam as insígnias de uma classe privilegiada, que se tornava realidade na vida de Emma por intermédio do Monsieur Lheureux, o qual lhe apresentava e lhe persuadia a compra das mercadorias luxuosas que articulavam o consumo e o ócio conspícuos.

Outro aspecto evidenciado no consumo de Emma refere-se ao que Veblen (1899) chamou de "emulação pecuniária", que é quando pessoas de classes sociais mais baixas tentam imitar as práticas de consumo daqueles que lhes são socialmente "superiores", como tentativa de mostrar sua afiliação aos grupos dominantes da sociedade.

Para Gomes (2012), Emma consumia de forma conspícua, para aparecer, mostrar e exibirse para a sociedade, utilizando-se de revistas e folhetins que lhes ensinava a imitar o que a classe superior valorizava, trazendo para dentro de sua vida bens que não pertenciam à sua classe, mas faziam parte do mundo no qual ela desejava se inserir.

A imitação pecuniária estaria, na visão de Veblen (1899), firmemente arraigada na ideia de propriedade, de posse, uma vez que os bens de consumo são adquiridos como símbolos de status e afiliação de classe social à identidade e ao estilo de vida de um dado grupo social.

Para a antropóloga Laura Gomes (2012), a tensão em Madame Bovary é marcada pelas escolhas e decisões que ela toma a partir do rompimento com o habitus ${ }^{7}$ de seu grupo social,

\footnotetext{
7 Habitus é entendido como um "sistema de disposições duráveis e transponíveis que, integrando todas as experiências passadas, funciona a cada momento como uma matriz de percepções, de apreciadores e de ações e torna possível a realização de tarefas infinitamente diferenciadas, graças as transferências analógicas de
} 
que estabelecia normas éticas e certo comedimento, e busca adquirir para si os emblemas em uma classe mais elevada, desenvolvendo um gosto luxuoso, requintado e extravagante.

Veblen (1899) alega que as pessoas comparam aquilo que têm com o que os outros ao seu redor possuem. Assim, os indivíduos, ou grupos estão sujeitos às pressões decorrentes das comparações que possibilitam a classificação social. Para o autor, o progresso de emulação pecuniária não garante a acumulação de respeito ou prestígio social; entretanto, os novos ricos adquirem objetos caros e de luxo, visando mostrar sua nova condição social.

No caso de Emma Bovary, ao ostentar hábitos de consumo dos membros das classes mais elevadas, ela busca um prestígio social que ultrapassava os meios financeiros de que dispunha, o que a levou a dilapidar o patrimônio da família.

Inspirando-se em Weber (1905), Campbell (1987) desenvolve a teoria de que as emoções e os desejos hedonistas que guiam a cultura de consumo estão fixados nos ideais do Romantismo do século XIX, que adveio logo após o lluminismo e a Revolução Industrial. Cenário este onde se desenvolve o drama social de Emma Bovary.

Embora o iluminismo concebesse os indivíduos como racionais, trabalhadores e autodisciplinados, Campbell (1987) destaca que os românticos viam tal fato como uma negação da essência da humanidade e enfatizavam que a intuição estava acima da razão e que o indivíduo deveria ser livre para buscar prazeres hedonistas e sentimentos novos e interessantes.

Para o autor, a ética romântica difundida pela classe média burguesa e pela cultura consumista é expressa como um ciclo no qual os indivíduos projetam seu desejo nos bens de consumo e compram esses bens. Quando o valor esperado se esgota, surge novamente a necessidade de consumir novos produtos que possam realizar esses novos desejos.

Assim, os indivíduos são uma vez mais estimulados pelo desejo de novos itens de consumo, repetindo-se o ciclo de consumo, de satisfação efêmera e desilusão (CAMPBELL, 1987). Desse modo, tanto os amantes quanto os objetos de luxo eram para Emma elementos de uma equivocada completude, fontes de um mesmo prazer, advindo do desejo de preencher o vazio e da ambição por uma vida diferente da sua, uma maneira de lutar contra as misérias da condição feminina (AGRA, 2015).

Para Gomes (2012), o romance de Madame Bovary foi o primeiro registro do consumidor moderno "face a face com os dilemas éticos advindos de suas escolhas, baseadas cada vez menos em critérios de necessidade, mas atendendo ao exercício do gosto e à busca do prazer e da felicidade pessoal em detrimento da felicidade coletiva". Em uma visão pragmática e 
pessimista, Roland Barthes (1988) e Jean Baudrillard (1995) defendem que o triunfo da cultura de consumo deve ser combatido. Barthes (1988) considera que a indústria da propaganda desempenha o papel de dificultar a visão dos consumidores quanto às suas verdadeiras vontades e desejos, ao passo que Baudrillard (1995) considera que a mídia é a responsável por bombardear o consumidor e ocultar a natureza vazia da moderna sociedade capitalista.

No caso de Emma, seu consumismo reportava a uma necessidade social de ser socialmente reconhecida, admirada e ter um amor correspondido. Santos (2006) menciona que Emma, ao entregar-se ao consumo, parecia tentar preencher suas faltas, suas carências e seu vazio existencial. Ela não resistiu às suas paixões pelo fato de suas forças não serem maiores que as paixões que a moveram em atos que a levaram à destruição.

Desse modo, Campbell (1987) considera equivocado sugerir que o consumismo seja algo inteiramente ruim, pois a busca e a projeção de desejos mais profundos sobre os bens de consumo propiciam a autorrealização do indivíduo no mundo moderno, mesmo que momentaneamente.

No caso de Emma Bovary, a grande polêmica relacionada ao consumo se deve ao fato do gosto requintado que lhe era apresentado ser incompatível com a sua condição social. Muito provavelmente, se Emma pertencesse a uma camada social mais elevada, seu gosto e seu consumo não causariam polêmica ou atrito, uma vez que a aristocracia possui um habitus que contribui para o sistema de valoração desses bens, além do esbanjamento e da lapidação serem fatos comuns nesse grupo social.

Entretanto, a necessidade de Emma em consumir poderia estar relacionada a uma insatisfação pessoal e à busca pela felicidade, que ainda hoje, no século XXI, tem a mídia como estimulador apresentando essa possibilidade ao acesso de todos, bastando, para isso, consumir os produtos que o mercado oferece.

A trama do romance sugere que Emma consumia mais para compensar suas insatisfações íntimas, em busca da felicidade, do que para tentar imitar ou fazer parte de uma classe mais elevada. Emma tentava "consumir a felicidade" investindo no que era possível; entretanto, o consumismo não proporcionou a felicidade duradoura que ela almejava, apenas uma felicidade efêmera e momentânea. 


\section{CONSIDERAÇÕES FINAIS}

O romance Madame Bovary foi e ainda é notoriamente objeto de polêmicas ao dar vida a uma mulher transgressora da moral e dos costumes, pregados pela sociedade da época que determinava o estereótipo de mulher ideal a ser seguido.

Ao se entregar às paixões e ao luxo, Emma desafiava o seu tempo e o seu meio social. A obra realista antecipa em um século alguns dos valores de libertação e emancipação da mulher defendidos pelo movimento feminista na segunda metade do século XX.

Emma Bovary foi mais uma vítima do que Rago (2015) chama de "tirania da intimidade" que afeta tanto mulheres quanto homens na sociedade moderna. Essa tirania se dá pela vida limitada pelos filhos, contas a pagar, atritos entre os cônjuges, deslocamento para o trabalho, rotina da vida em família etc., o que pode levar as pessoas à claustrofobia e à depressão, considerada o mal-estar contemporâneo; no caso dos homens, identificado como melancolia, e das mulheres, "histeria".

Embora a trama do romance tenha se passado há quase dois séculos, a sociedade moderna contemporânea ainda prega valores semelhantes por meio da ideologia da domesticidade, do modelo de família nuclear como o ideal imaginário, do confinamento da mulher em identidades e papéis sociais, da aprovação somente da formação cristã, da normatização da vida social, dentre outros.

A ordem social, por meio de leis rígidas, nega às pessoas o direito ao prazer, à realização de seus desejos e à construção de um discurso mais flexível que as inclua na transformação da sociedade. Nesse sentido, homens e mulheres têm buscado serem sujeitos de sua história e participar da história de seu tempo, o que é alcançado, principalmente, com a autonomia decorrente da vida profissional e financeira, bem como com a participação política.

Em relação ao consumo como drama social de Madame Bovary, o autor antecipa a percepção da sua importância para a subjetividade moderna, revelando as principais características que este adquire no universo social atual, dentre as quais está a relevância de se considerar o que se passa no íntimo do indivíduo, uma vez que isso pode atuar como mola propulsora do desejo de consumir e uma consequente insaciabilidade.

Emma, entregue ao ócio, às paixões e à necessidade de atingir seus objetivos de viver uma vida diferente da que levava, deixou-se enredar pela literatura, pelo romantismo e pelo consumismo, como formas de fuga de sua realidade, para viver um mundo de fantasias que lhe oferecia possibilidades que o mundo concreto não lhe oferecia. 
O romance Madame Bovary denuncia a forma como a mulher do século XIX era objetificada, não possuía liberdade e nem direitos. Enquanto a maioria das mulheres se conformavam aos padrões, Emma rompeu seus limites, mas não conseguiu um agenciamento para si e para as mulheres de seu tempo.

O contexto social da trama do romance Madame Bovary ainda se mostra muito presente nos dias atuais, principalmente, no que se refere às questões de gênero. Embora muita coisa tenha se modificado, muitas conquistas tenham sido alcançadas, diversos mecanismos, dentre eles a mídia, tentam manter a mulher na condição de objetificada, subordinada e inferiorizada em relação ao homem na sociedade. Tal fato requer uma luta constante para modificar essa concepção e redefinir esse lugar determinado para ela pela sociedade. Nesse sentido, Emma pode ser qualquer uma de nós.

Embora o romance traga a ideia da subversão às normas sociais, a impossibilidade de sair do problema que Emma criou, o que culmina com o suicídio, este acaba se revelando como um mecanismo de manutenção da ordem social ao destacar o destino das mulheres que tentam subverter a ordem.

Por fim, embora o romance seja uma clara crítica à sociedade burguesa em relação aos papéis predefinidos para a mulher, ele reitera a ideia de que a mulher que subverte a ordem social receberá o julgamento da sociedade ou um fim mais trágico, como o de Emma, por não suportar o peso das contradições sociais a que foi exposta.

\section{REFERÊNCIAS}

AGRA, Ana Maria. Madame Bovary: uma morte de gênero. Revista Ártemis, v. XIX, p. 82-89. 2015. Ecrossref

BADINTER, Elizabeth. O amor ausente. In: materno. 8. ed. Rio de Janeiro: Nova Fronteira, 1995.

Um amor conquistado: o mito do amor

BARTHES, Roland. O desafio semiótico. Nova York: André Wang. 1988.

BAUDRILLARD, Jean. A sociedade de consumo. São Paulo: Elfos. 1995.

BEAUVIOR, Simone. O segundo sexo. v. 2. 4. ed. Rio de Janeiro: Nova Fronteira, 1970.

BOURDIEU, Pierre. Sociologia. In: Ortiz R. Pierre Bourdieu. São Paulo: Ática, 1983.

CAMPBELL, Colin. A ética romântica e o espírito do consumismo moderno. Rio de Janeiro: Rocco, 2001. 
FLAUBERT, Gustave. Madame Bovary. Porto Alegre: L\&PM, 2016.

FRIEDAN, Betty. O problema sem nome. In: . A mística feminina. Petrópolis - RJ: Vozes, 1971.

GOMES, Laura Graziela. Madame Bovary - a mulher e o consumo conspícuo feminino. São Paulo. 01 de agosto de 2012. Disponível em: <https://bit.ly/2WJphAs. Acesso em: 04 jun. 2018.

HEINEBERG, Ilana. Biografia de Gustave Flaubert. In: FLAUBERT, Gustave. Madame Bovary. Tradução. Porto Alegre: L\&PM, 2016.

MEDEIROS, Luana Pantoja; MEDEIROS, Alexsandro Melo. Madame Bovary: a desconstrução do eterno feminino na literatura francesa do século XIX. IV SINALGE - Simpósio Nacional de Linguagens e Gêneros Textuais, Anais... Campina Grande - PB, abril de 2017.

MICHILES, Haroldo César. Sombra e feminismo em Madame Bovary. IJUSP - Instituto Junguiano de São Paulo. Especialização em Psicoterapia Junguiana. Brasília, 2012. Disponível em: < http://institutojunguianorj.org.br/sombra-e-feminismo-em-madame-bovary/>.

NYE, Andrea. Introdução: Os propósitos da teoria feminista. Liberté, Égalité e Fraternité: liberalismo e direitos das mulheres no século XIX. In: NYE, Andrea. Teoria feminista e as filosofias do homem. Rio de Janeiro: Record/Rosa dos Tempos, p. 13-47. 1995.

ORTNER, Sherry B. Está a mulher para o homem assim como a natureza para a cultura? In: Rosaldo, M.; Lamphere, L. (orgs). A mulher, a cultura, a sociedade. Rio de Janeiro: Paz e Terra, 1979. p. 95-120. Disponível em: <https://bit.ly/Vaq4tZ>.. Acesso em: 11 jun. 2018.

PINTO, Céli Regina Jardim. Uma história do feminismo no Brasil. São Paulo: Fundação Perseu Abramo. 2003.

PRESCINCA, Miriam. Contexto histórico e crítica social da obra: Madame Bovary. Aracajú, 07 ago. 2013. Disponível em: <https://bit.ly/2CQoOog>. Acesso em: 19 jun. 2018.

RAGO, Margareth. Madame Bovary e a reinvenção da mulher. Entrevista concedida ao Café Filosófico. São Paulo, 10 abr. $2015 . \quad$ Disponível em: <http://www.institutocpfl.org.br/2015/04/07/madame-bovary-e-a-reinvencao-da-mulher/>. Acesso em: 20 jun. 2018. 
SANTOS, Goiamérico Felício Carneiro dos. Madame Bovary: a paixão, o consumo. Cerrados (UnB), v. 01, p. 79-90, 2006.

VEBLEN, Thorstein Bunde. A teoria da classe ociosa: um estudo econômico das instituições. São Paulo: Pioneira, 1965.

WEBER, Max. A ética protestante e o espírito capitalista.São Paulo: Pioneira. 5 ed. 1987. 